\title{
European Critical Loads of Cadmium, Lead and Mercury and their Exceedances
}

\author{
J. Slootweg • J.-P. Hettelingh • M. Posch • \\ G. Schütze • T. Spranger • W. de Vries • \\ G. J. Reinds • M. van 't Zelfde • \\ S. Dutchak • I. Ilyin
}

Received: 17 June 2005 / Accepted: 12 February 2006 / Published online: 30 January 2007

(C) Springer Science + Business Media B.V. 2007

\begin{abstract}
Critical loads of cadmium, lead and mercury were computed by 18 countries of the LRTAP Convention. These national data were collated into a single database for the purpose of identifying sensi-
\end{abstract}

J. Slootweg $\cdot$ J.-P. Hettelingh $(\bowtie) \cdot$ M. Posch

Coordination Centre for Effects, Netherlands

Environmental Assessment Agency (MNP),

P.O. Box 303, 3720 AH Bilthoven, The Netherlands

e-mail: j.p.hettelingh@mnp.nl

G. Schütze

OEKO-DATA,

Hegermuehlenstrasse 58,

15344 Strausberg, Germany

T. Spranger

Umweltbundesamt (UBA),

P.O. Box 1406, 6813 Dessau, Germany

W. de Vries $\cdot$ G. J. Reinds

Alterra, Wageningen University

and Research Centre (WUR),

P.O. Box 47, 6700 AA Wageningen, The Netherlands

M. van 't Zelfde

Institute of Environmental Sciences (CML),

Leiden University,

P.O. Box 9518, 2300 RA Leiden, The Netherlands

S. Dutchak $\cdot$ I. Ilyin

EMEP/MSC - East,

Ul. Arhitektor Vlasov 51,

117393 Moscow, Russian Federation tive areas in Europe. Computing exceedances, i.e. comparing the critical loads to atmospheric deposition, shows that cadmium was not a widespread risk in 2000, that the risk from lead deposition has decreased since 1990 but was still widespread in 2000 , and that the risk from mercury remains high without much change from 1990 to 2000 in most of the countries.

Keywords atmospheric deposition · critical loads . heavy metals · exceedances · LRTAP Convention

\section{Introduction}

Critical loads of cadmium $(\mathrm{Cd})$, lead $(\mathrm{Pb})$ and mercury $(\mathrm{Hg})$ are derived for European ecosystems using human and environmental endpoints in the framework of activities of the Coordination Centre for Effects (CCE) of the ICP M\&M under the Convention on Long-range Transboundary Air Pollution (LRTAP). A methodology was developed under the LRTAP Convention and published in the Mapping Manual (UBA, 2004). This paper summarizes the methodology to assess critical loads of $\mathrm{Cd}, \mathrm{Pb}$, and $\mathrm{Hg}$ and provides an overview of the risk that deposition of these metals causes. A complete description of the results can be found in Slootweg, Hettelingh, Posch, Dutchak, and Ilyin (2005). 


\section{Methodology}

The critical load of a metal is its highest total input rate from anthropogenic sources to an ecosystem, below which harmful effects on human health, or ecosystem structure and function will not occur over the long-term, according to present knowledge. The critical load is derived with a biogeochemical model, assuming steadystate for the metal fluxes as well as chemical equilibrium consistent with concepts of sustainability. The concentrations in these fluxes are set to thresholds (critical limits), below which significant harmful effects on human health or specified sensitive elements of the environment do not occur.

Critical loads of cadmium, lead and mercury were calculated addressing either ecotoxicological effects on aquatic and terrestrial ecosystems or human health effects. Table 1 presents some possible effects of the three metals that were considered for the critical load assessment.

For simplicity, and consistency with the steadystate mass balance used for nitrogen and acidity critical loads, internal metal cycling within ecosystems is ignored. Weathering inputs of metals are also neglected due to 1) low weathering inputs and 2) high uncertainties of respective calculations.

\subsection{Terrestrial Ecosystems}

For terrestrial ecosystems (effects 1, 2 and 3 in Table 1) the critical load of a metal equals the sum of tolerable net metal uptake by plants and metal leaching:

$\mathrm{CL}(M)=M_{\mathrm{u}}+M_{\mathrm{le}(\text { crit })}$

where:

$\mathrm{CL}(M) \quad$ critical load of metal $M\left(\mathrm{~g} \mathrm{ha}^{-1} \mathrm{a}^{-1}\right)$

$M_{\mathrm{u}} \quad$ net metal uptake in harvestable parts of plants under critical load conditions (g ha ${ }^{-1} \mathrm{a}^{-1}$ )

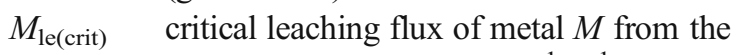
considered soil layer ( $\mathrm{g} \mathrm{ha}^{-1} \mathrm{a}^{-1}$ ), whereby only the vertical flux is considered.

The soil depth, for which critical load are calculated, depends on the receptor and the ecosystem type. The net uptake of metals by plants "under critical load conditions" is calculated as \{production of harvestable biomass $\times$ \{metal concentration in the harvested parts\}. For most plant species the uptake cannot be related to a critical concentration in soil or soil solution, because respective reliable transfer functions are missing. An exception is the relationship of $\mathrm{Cd}$ in soil solution to $\mathrm{Cd}$ in wheat grains. This transfer function is used to derive a critical concentration in the soil solution from a critical limit for $\mathrm{Cd}$ in wheat, while the uptake is calculated by grain production times this critical limit ( $0.1 \mathrm{mg} \mathrm{kg}^{-1}$ fresh weight in the grain), aiming at critical loads related to human health.

The critical leaching is calculated from the water flux percolating through the soil (soil drainage water) and a critical concentration in this flux. Critical total

Table 1 Overview of indicators used in the computation of critical thresholds

\begin{tabular}{|c|c|c|c|c|c|}
\hline $\begin{array}{l}\text { Receptor } \\
\text { Ecosystem }\end{array}$ & Endpoints & $\begin{array}{l}\text { Heavy metals } \\
\text { of concern }\end{array}$ & $\begin{array}{l}\text { Land cover types to be } \\
\text { considered }\end{array}$ & Indicator/critical limit & $\begin{array}{l}\text { Effect } \\
\text { number }\end{array}$ \\
\hline \multirow[t]{5}{*}{ Terrestrial } & \multirow[t]{3}{*}{$\begin{array}{r}\text { Human } \\
\text { health }\end{array}$} & $\mathrm{Cd}, \mathrm{Pb}, \mathrm{Hg}$ & All ecosystems & $\begin{array}{l}\text { Total concentration in soil water below the rooting zone } \\
\text { (to protect ground water) }\end{array}$ & 1 \\
\hline & & $\mathrm{Cd}, \mathrm{Pb}, \mathrm{Hg}$ & Arable land & Content in food, fodder and crops & 2 \\
\hline & & $\mathrm{Cd}, \mathrm{Pb}, \mathrm{Hg}$ & Grassland & Content in grass and animal products (cows, sheep) & \\
\hline & \multirow[t]{2}{*}{$\begin{array}{l}\text { Ecosystem } \\
\text { functions }\end{array}$} & $\mathrm{Cd}, \mathrm{Pb}$ & $\begin{array}{l}\text { Arable land, grassland, } \\
\text { non-agricultural }\end{array}$ & $\begin{array}{l}\text { Free ion concentration in view of effects on soil micro- } \\
\text { organisms, plants and invertebrates }\end{array}$ & 3 \\
\hline & & $\mathrm{Hg}$ & Forest soils & $\begin{array}{l}\text { Total concentration in humus layer in view of effects } \\
\text { on soil micro organisms and invertebrates }\end{array}$ & \\
\hline \multirow[t]{2}{*}{ Aquatic } & $\begin{array}{l}\text { Ecosystem } \\
\text { functions }\end{array}$ & $\mathrm{Cd}, \mathrm{Pb}, \mathrm{Hg}$ & Freshwaters & $\begin{array}{l}\text { Total concentration in view of effects on algae, } \\
\text { crustacea, worms, fish, top predators }\end{array}$ & 4 \\
\hline & $\begin{array}{c}\text { Human } \\
\text { health }\end{array}$ & $\mathrm{Hg}$ & Freshwaters & Concentration in fish & 5 \\
\hline
\end{tabular}


concentrations of $\mathrm{Cd}, \mathrm{Pb}$ and $\mathrm{Hg}$ in the soil drainage water depend on the target to be protected. These values are derived from receptor-specific critical limits (see Table 1) which are (for details see De Vries et al., 2004; UBA, 2004):

- Critical Cd contents in wheat grains in view of human health effects through intake of plant products (see above).

- Critical metal concentrations in ground water $(\mathrm{Cd}$, $\mathrm{Pb}, \mathrm{Hg}$ ) in view of human health effects through intake of drinking water. The guidance values of the WHO (2004) can directly be used.

- Critical concentrations of free metal ions (FMI) in soil solution $(\mathrm{Cd}, \mathrm{Pb})$ in view of ecotoxicological effects on soil micro-organisms, plants, and invertebrates. FMI must be converted to the total concentration in soil drainage water by using a chemical speciation model. Here pH-dependent critical FMI concentration is used, based on an evaluation of NOEC (No Observable Effect Concentration) soil data combined with a transfer function relating the critical concentration in solid soil to that in soil solution. Only data sets were used in which the needed soil properties to apply those functions ( $\mathrm{pH}$ and organic matter content) were available.

- Critical Hg concentration in soil organic matter $(0.5 \mathrm{mg} \mathrm{Hg} / \mathrm{kg}$ organic matter) in view of ecotoxicological effects on soil micro-organisms and invertebrates in the forest floor. Soil Hg concentration can be converted to a total $\mathrm{Hg}$ concentration in soil drainage water by using a transfer function based on dissolved organic matter concentration in the soil solution.

\subsection{Aquatic Ecosystems}

As with terrestrial ecosystems, the critical load of $\mathrm{Cd}$ and $\mathrm{Pb}$ for freshwaters (effect 4 in Table 1) is given by Eq. 1 where $M_{\mathrm{u}}$ is the average net uptake in the catchment $\left(\mathrm{g} \mathrm{ha}^{-1} \mathrm{a}^{-1}\right.$ ) and the leaching has to be replaced by critical outflow of metal from the whole catchment $\left(\mathrm{g} \mathrm{ha}^{-1} \mathrm{a}^{-1}\right)$. A retention term can be added to the basic equation, in particular in calculations for lakes, if the information is available. Neglecting this term leads to a more conservative estimate.

The critical dissolved concentration of $\mathrm{Cd}$ $\left(0.38 \mathrm{mg} \mathrm{m}^{-3}\right)$ in the outflow is based on the EU risk assessment for cadmium metal (EC, 2003). The value for $\mathrm{Pb}\left(11 \mathrm{mg} \mathrm{m}^{-3}\right)$ is based on Crommentuijn, Polder, and Van de Plassche (1997). These concentrations have to be converted into total concentrations, accounting for metals bound to suspended particles.

A different approach was used to calculate critical concentration levels of $\mathrm{Hg}$ in atmospheric precipitation, to protect against effect 5 (Table 1). This approach aims at the protection of fish used for human food consumption. The recommended critical limit for $\mathrm{Hg}$ is $0.3 \mathrm{mg} \mathrm{kg}^{-1}$ (fresh weight). Using a 1$\mathrm{kg}$ pike (Esox lucius) as a standard receptor (to which $\mathrm{Hg}$ concentrations in other organisms can be related) the $\mathrm{Hg}$ concentration in fish flesh is related to the mean $\mathrm{Hg}$ concentration in precipitation at a given site and the critical level of atmospheric pollution is thus calculated as follows:

$[\mathrm{Hg}]_{\text {Prec(crit) }}=[\mathrm{Hg}]_{\text {Pike(crit) }} /\left(\mathrm{TF}_{\mathrm{HgSite}} \cdot \mathrm{c}_{\mathrm{bp}}\right)$

where:

$[\mathrm{Hg}]_{\text {Prec(crit) }}$ critical Hg concentration in precipitation (ng $1^{-1}$ )

$[\mathrm{Hg}]_{\text {Pike(crit) }}$ critical Hg concentration in the flesh of $1-\mathrm{kg}$ pike $\left(0.3 \mathrm{mg} \mathrm{kg}^{-1}\right.$ fresh weight)

$\mathrm{TF}_{\mathrm{HgSite}} \quad$ site-specific transfer function $\left(\mathrm{l} \mathrm{kg}^{-1}\right.$ fresh weight) referring to the transfer of atmospheric $\mathrm{Hg}$ to fish flesh in a watershed at steady state

$\mathrm{c}_{\mathrm{bp}} \quad 10^{-6} \mathrm{mg} \mathrm{ng}^{-1}$, factor for appropriate conversion of units.

Information on the critical loads methodology of heavy metals can be obtained from the Manual of the ICP Modelling \& Mapping (UBA, 2004). Details of the methodology are described in a separate background document (De Vries et al., 2004). In principle the countries were encouraged to use national input data to calculate critical loads. The Manual provides default values, if own data are missing.

\section{Results}

\subsection{Critical Loads}

Altogether, 18 countries submitted critical loads of heavy metals. Critical loads of cadmium, lead and mercury were computed by 17,17 , and 10 countries, 
respectively. However not all countries addressed all effects, as is shown in Table 2. It shows that most countries computed critical loads for effects 1 and 3 .

The European synthesis of the country submissions was done as follows. For each ecosystem the minimum critical load of health effects (effects 1,2) was taken. The same was done for ecosystem effects (effects 3, 4). Then for each EMEP50 grid cell and for each metal, the fifth percentile of the distribution of these minimum critical loads is calculated for health effects, and ecosystem effects separately. Figure 1 shows the fifth percentile of the minimum critical loads for human health (left) and ecosystem health (right) of $\mathrm{Cd}$ (top), $\mathrm{Pb}$ (middle) and $\mathrm{Hg}$ (bottom). Red areas indicate most sensitive areas.

Effect 5 (not shown here) is treated separately because it is not associated with a critical deposition but with a critical concentration in precipitation. In addition, only three countries (Finland, Sweden and Belgium) submitted critical loads for this effect. It turns out (Slootweg et al., 2005) that the distribution of critical concentrations roughly lies between 0.5 and $5 \mathrm{ng}^{-1}$.

\subsection{Critical Load Exceedances}

Depositions were computed with a long-range atmospheric dispersion model by the EMEP Meteorological Synthesizing Centre East under the LRTAP Convention. The methods used are described in Ilyin and Dutchak (2005).

Depositions were compared to critical loads to identify areas where ecosystems are at risk, i.e. where deposition exceeds critical loads. Tables 3 and 4 show that the risks of effects of lead are more widespread than those of cadmium.

The area of excess deposition of $\mathrm{Pb}$ in 2000 is strongly reduced in comparison to 1990 (Tables 3 and 4). In Europe $33.8 \%$ of the ecosystem area in 1990 was subjected to excess deposition of $\mathrm{Pb}$ for human health effects, which was reduced to $8.3 \%$ in 2000 (Table 3). The risk for ecosystem effects of $\mathrm{Pb}$ dropped from $65.7 \%$ in 1990 to $28.7 \%$ in 2000 (Table 4).

A preliminary analysis of the risk of cadmium and lead caused by agricultural practices was conducted on data available for a few countries, i.e. Austria, Germany, Italy, Sweden, The Netherlands and the

Table 2 Overview of available national data on critical loads of cadmium, lead and mercury for the five effects

\begin{tabular}{|c|c|c|c|c|c|c|c|c|c|c|c|c|}
\hline \multirow[t]{3}{*}{ Country } & \multirow[t]{3}{*}{ Country code } & \multicolumn{11}{|c|}{ Effect number (Table 1) } \\
\hline & & \multicolumn{4}{|l|}{$\mathrm{Cd}$} & \multicolumn{4}{|l|}{$\mathrm{Pb}$} & \multicolumn{3}{|c|}{$\mathrm{Hg}$} \\
\hline & & 1 & 2 & 3 & 4 & 1 & 2 & 3 & 4 & 1 & 3 & 5 \\
\hline Austria & AT & $\mathrm{x}$ & $\mathrm{x}$ & $\mathrm{x}$ & & $\mathrm{x}$ & & $\mathrm{x}$ & & $\mathrm{x}$ & $\mathrm{x}$ & \\
\hline Belarus & BY & & & $\mathrm{x}$ & & & & $\mathrm{x}$ & & & & \\
\hline Belgium & $\mathrm{BE}$ & $\mathrm{x}$ & & $\mathrm{x}$ & $\mathrm{x}$ & $\mathrm{x}$ & & $\mathrm{x}$ & $\mathrm{x}$ & $\mathrm{x}$ & $\mathrm{x}$ & $\mathrm{x}$ \\
\hline Bulgaria & BG & $\mathrm{x}$ & & & & $\mathrm{x}$ & & & & & & \\
\hline Cyprus & $\mathrm{CY}$ & $\mathrm{x}$ & $\mathrm{x}$ & $\mathrm{x}$ & & $\mathrm{x}$ & & $\mathrm{x}$ & & $\mathrm{x}$ & & \\
\hline Czech Republic & $\mathrm{CZ}$ & $\mathrm{x}$ & & & & $\mathrm{x}$ & & & & $\mathrm{x}$ & & \\
\hline Finland & FI & & & & & & & & & & & $\mathrm{x}$ \\
\hline France & FR & & & $\mathrm{x}$ & & & & $\mathrm{x}$ & & & & \\
\hline Germany & $\mathrm{DE}$ & $\mathrm{x}$ & $\mathrm{x}$ & $\mathrm{x}$ & & $\mathrm{x}$ & & $\mathrm{x}$ & & $\mathrm{x}$ & $\mathrm{x}$ & \\
\hline Italy & IT & & & $\mathrm{x}$ & & & & $\mathrm{x}$ & & & & \\
\hline The Netherlands & NL & $\mathrm{x}$ & $\mathrm{x}$ & $\mathrm{x}$ & & $\mathrm{x}$ & & $\mathrm{x}$ & & & & \\
\hline Poland & PL & & & $\mathrm{x}$ & & & & $\mathrm{x}$ & & & $\mathrm{x}$ & \\
\hline Russia & RU & $\mathrm{x}$ & & $\mathrm{x}$ & & $\mathrm{x}$ & & $\mathrm{x}$ & & & & \\
\hline Slovakia & SK & & & $\mathrm{x}$ & & & & $\mathrm{x}$ & & & $\mathrm{x}$ & \\
\hline Sweden & SE & & $\mathrm{x}$ & $\mathrm{x}$ & & & & $\mathrm{x}$ & & & $\mathrm{x}$ & $\mathrm{x}$ \\
\hline Switzerland & $\mathrm{CH}$ & $\mathrm{x}$ & & $\mathrm{x}$ & & $\mathrm{x}$ & & $\mathrm{x}$ & & & $\mathrm{x}$ & \\
\hline Ukraine & UA & & $\mathrm{x}$ & & & & $\mathrm{x}$ & & & & & \\
\hline UK & GB & & & $\mathrm{x}$ & & & & $\mathrm{x}$ & & & & \\
\hline Total & 18 & 10 & 6 & 14 & 1 & 10 & 1 & 14 & 1 & 6 & 7 & 3 \\
\hline
\end{tabular}


Fig. 1 Critical loads of cadmium (top), lead (middle) and mercury (bottom) showing maximum allowable atmospheric depositions (see shadings) to protect $95 \%$ of the ecosystems from risks for human health (left) and ecosystem health (right). Red and blue shaded areas indicate the most and least sensitive areas, respectively
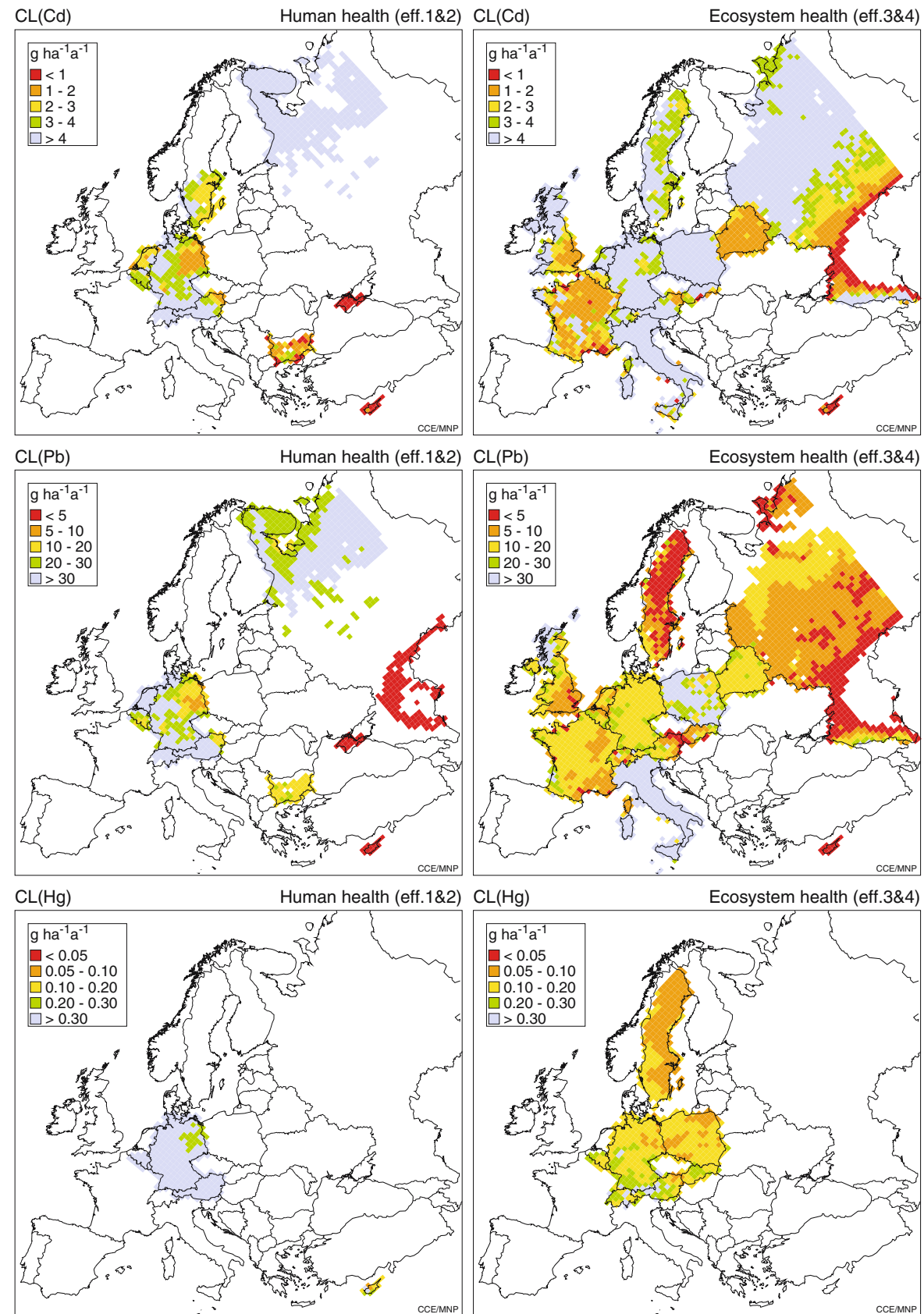

Ukraine. This analysis revealed that agricultural input of $\mathrm{Cd}$ without atmospheric input exceeds critical loads in only one grid cell in Germany. Added to atmospheric deposition, Cd critical loads of agricultural ecosystems in four German grid cells turn out to be exceeded. However, the critical loads of $\mathrm{Pb}$ are exceeded by agricultural inputs alone in Austria, the Netherlands and the Ukraine, including large parts of Germany when atmospheric depositions are added.
Critical concentrations in rainwater (effect 5) are exceeded in nearly all grid cells for which data was provided.

\section{Conclusions}

Critical loads of cadmium $(\mathrm{Cd})$, lead $(\mathrm{Pb})$ and mercury $(\mathrm{Hg})$ were computed by 17,17 , and 10 countries, respectively. The methodology used for calculating critical loads of heavy metals has been 
Table 3 Percentage of national ecosystem areas that are at risk of health effects in countries that submitted critical loads of cadmium, lead and/or mercury

\begin{tabular}{|c|c|c|c|c|c|c|c|c|c|}
\hline \multirow[t]{2}{*}{ Country } & \multicolumn{3}{|c|}{ Cadmium $(\mathrm{Cd})$} & \multicolumn{3}{|l|}{ Lead $(\mathrm{Pb})$} & \multicolumn{3}{|c|}{ Mercury (Hg) } \\
\hline & $\begin{array}{l}\text { Eco area } \\
\left(\mathrm{km}^{2}\right)\end{array}$ & $\begin{array}{l}1990 \text { at risk } \\
(\%)\end{array}$ & $\begin{array}{l}2000 \text { at risk } \\
(\%)\end{array}$ & $\begin{array}{l}\text { Eco area } \\
\left(\mathrm{km}^{2}\right)\end{array}$ & $\begin{array}{l}1990 \text { at risk } \\
(\%)\end{array}$ & $\begin{array}{l}2000 \text { at risk } \\
(\%)\end{array}$ & $\begin{array}{l}\text { Eco area } \\
\left(\mathrm{km}^{2}\right)\end{array}$ & $\begin{array}{l}1990 \text { at risk } \\
(\%)\end{array}$ & $\begin{array}{l}2000 \text { at risk } \\
(\%)\end{array}$ \\
\hline AT & 61,371 & 0.0 & 0.0 & 61,371 & 24.0 & 0.0 & 61,371 & 0.0 & 0.0 \\
\hline $\mathrm{BE}$ & 5,228 & 0.0 & 0.0 & 5,228 & 62.3 & 18.2 & 5,228 & 22.7 & 6.1 \\
\hline BG & 48,330 & 42.0 & 14.8 & 48,330 & 99.9 & 77.2 & - & - & - \\
\hline $\mathrm{CH}$ & 2,200 & 0.0 & 0.0 & 2,218 & 72.0 & 2.3 & - & - & - \\
\hline $\mathrm{CY}$ & 7,973 & 1.3 & 0.8 & 7,973 & 74.1 & 70.4 & 7,973 & 4.2 & 4.1 \\
\hline $\mathrm{CZ}$ & 25,136 & 1.1 & 0.5 & 25,136 & 93.1 & 19.9 & 25,136 & 7.4 & 1.9 \\
\hline $\mathrm{DE}$ & 290,003 & 1.4 & 0.1 & 290,003 & 79.0 & 7.4 & 290,003 & 17.9 & 4.8 \\
\hline NL & 19,471 & 0.1 & 0.0 & 19,471 & 89.2 & 0.1 & - & - & - \\
\hline RU & 425,425 & 0.0 & 0.0 & 650,575 & 3.3 & 2.5 & - & - & - \\
\hline SE & 22,050 & 0.0 & 0.0 & - & - & - & - & - & - \\
\hline UA & 18,002 & 0.0 & 0.0 & 18,002 & 91.6 & 41.4 & - & - & - \\
\hline EU25 & 431,232 & 1.1 & 0.1 & 409,182 & 71.8 & 8.1 & 389,711 & 14.2 & 3.9 \\
\hline Europe & 925,190 & 2.7 & 0.8 & $1,128,308$ & 33.8 & 8.3 & 389,711 & 14.2 & 3.9 \\
\hline
\end{tabular}

carefully reviewed and is documented in the Mapping Manual of the ICP on Modelling and Mapping. The methodology enabled the assessment of ecosystem specific critical loads to protect human or environmental health. These critical loads were compared to preliminary computations of ecosystem specific deposition of the respective metals in 1990 and 2000. The robustness of deposition results can not yet well be established due to the many uncertainties. Bearing these uncertainties in mind, atmospheric deposition of $\mathrm{Cd}$ did not cause widespread risk in 2000 , that the risk of $\mathrm{Pb}$ deposition decreased after 1990 but was still widespread in 2000 and, finally, that the risk caused by $\mathrm{Hg}$ did not change much from 1990 to 2000 in

Table 4 Percentage of national ecosystem areas that are at risk of ecosystem effects in countries that submitted critical loads of cadmium, lead and/or mercury

\begin{tabular}{|c|c|c|c|c|c|c|c|c|c|}
\hline \multirow[t]{2}{*}{ Country } & \multicolumn{3}{|c|}{ Cadmium (Cd) } & \multicolumn{3}{|l|}{ Lead $(\mathrm{Pb})$} & \multicolumn{3}{|c|}{ Mercury (Hg) } \\
\hline & $\begin{array}{l}\text { Eco area } \\
\left(\mathrm{km}^{2}\right)\end{array}$ & $\begin{array}{l}1990 \text { at risk } \\
(\%)\end{array}$ & $\begin{array}{l}2000 \text { at risk } \\
(\%)\end{array}$ & $\begin{array}{l}\text { Eco area } \\
\left(\mathrm{km}^{2}\right)\end{array}$ & $\begin{array}{l}1990 \text { at risk } \\
(\%)\end{array}$ & $\begin{array}{l}2000 \text { at risk } \\
(\%)\end{array}$ & $\begin{array}{l}\text { Eco area } \\
\left(\mathrm{km}^{2}\right)\end{array}$ & $\begin{array}{l}1990 \text { at risk } \\
(\%)\end{array}$ & $\begin{array}{l}2000 \text { at risk } \\
(\%)\end{array}$ \\
\hline AT & 61,371 & 0.0 & 0.0 & 61,371 & 48.7 & 11.1 & 32,601 & 39.2 & 11.7 \\
\hline $\mathrm{BE}$ & 5,237 & 0.0 & 0.0 & 5,237 & 63.0 & 12.8 & 5,228 & 100.0 & 83.5 \\
\hline BY & 121,128 & 9.1 & 0.1 & 121,128 & 100.0 & 10.2 & - & - & - \\
\hline $\mathrm{CH}$ & 9,411 & 0.0 & 0.0 & 9,393 & 99.0 & 24.1 & 11,611 & 80.2 & 44.4 \\
\hline $\mathrm{CY}$ & 7,973 & 0.0 & 0.0 & 7,973 & 80.9 & 78.4 & - & - & - \\
\hline $\mathrm{DE}$ & 290,003 & 0.1 & 0.0 & 290,003 & 83.8 & 9.0 & 99,866 & 97.0 & 59.8 \\
\hline FR & 170,638 & 0.1 & 0.0 & 170,638 & 93.7 & 9.8 & - & - & - \\
\hline GB & 50,075 & 0.5 & 0.0 & 50,075 & 25.9 & 6.0 & - & - & - \\
\hline IT & 278,128 & 0.0 & 0.0 & 278,128 & 0.3 & 0.0 & - & - & - \\
\hline NL & 22,314 & 0.0 & 0.0 & 22,314 & 98.4 & 21.5 & - & - & - \\
\hline PL & 88,383 & 0.5 & 0.0 & 88,383 & 73.5 & 14.7 & 88,383 & 100.0 & 99.9 \\
\hline RU & $1,393,300$ & 1.1 & 0.2 & $1,194,125$ & 70.8 & 51.0 & - & - & - \\
\hline SE & 151,432 & 0.0 & 0.0 & 151,432 & 60.5 & 1.9 & 152,074 & 56.0 & 22.9 \\
\hline SK & 19,253 & 2.6 & 1.1 & 19,253 & 52.3 & 22.6 & 19,253 & 99.0 & 65.3 \\
\hline EU25 & $1,144,807$ & 0.1 & 0.0 & $1,144,807$ & 56.3 & 7.4 & 397,405 & 77.4 & 51.2 \\
\hline Europe & $2,668,646$ & 1.0 & 0.1 & $2,469,453$ & 65.7 & 28.7 & 409,016 & 77.4 & 51.0 \\
\hline
\end{tabular}


most of the countries that provided data on mercury. Agricultural input of $\mathrm{Cd}$ causes exceedance in a single grid cell. For $\mathrm{Pb}$ fertilisation alone does exceed critical loads, especially in the Netherlands. Added to atmospheric deposition, however, the critical load of $\mathrm{Pb}$ is exceeded also in central Germany.

\section{References}

Crommentuijn, T., Polder, M. D., \& Van de Plassche, E. J. (1997). Maximum permissible concentrations and negligible concentrations for metals, taking background concentrations into account, Report 601501001 (157 pp) Bilthoven, The Netherlands: National Institute for Public Health and the Environment.

De Vries, W., Schütze, G., Lofts, S., Tipping, E., Meili, M., Römkens, P. F. A. M., et al. (2004). Calculation of critical loads for cadmium, lead and mercury, Alterra Report 1104, Wageningen, The Netherlands, 143 pp.

EC (2003). Risk Assessment cadmium metal, CAS-No.: 744043-9, EINECS No 231-152-8, Draft risk assessment report in accordance with council regulation EEC 793/93.

Ilyin, I., \& Dutchak, S. (2005). Deposition modelling for heavy metals (pp. 39-60). In Slootweg et al. (Eds.) (op. cit.).

Slootweg, J., Hettelingh, J.-P., Posch, M., Dutchak, S., \& Ilyin, I. (Eds.) (2005). Critical loads of cadmium, lead and mercury in Europe, CCE-MSCE Collaborative report. Bilthoven, The Netherlands: Netherlands Environmental Assessment Agency, http://www.mnp.nl/cce.

UBA (2004). Manual on methodologies and criteria for modelling and mapping of critical loads and levels and air pollution effects, risks and trends, UBA-Texte 52/2004. Berlin, Germany: Federal Environmental Agency, http:// www.icpmapping.org.

WHO (2004). Guidelines for drinking water quality, 3rd edn (vol 1), recommendations. Geneva : World Health Organisation. 